\title{
Microbiological contamination of reindeer carcasses in different reindeer slaughterhouses
}

\author{
Vaarala, A. \\ International Association for Food Protection \\ 1999
}

Journal of food protection. 1999. 62: 152-155

http://hdl.handle.net/1975/762

Downloaded from Helda, University of Helsinki institutional repository.

This is an electronic reprint of the original article.

This reprint may differ from the original in pagination and typographic detail.

Please cite the original version. 


\title{
Microbiological Contamination of Reindeer Carcasses in Different Reindeer Slaughterhouses
}

\author{
AULI M. VAARALA AND HANNU J. KORKEALA* \\ Department of Food and Environmental Hygiene, Faculty of Veterinary Medicine, University of Helsinki, P.O. Box 57, FIN-00014 Helsinki \\ University, Finland
}

MS 98-118: Received 29 April 1998/Accepted 11 September 1998

\begin{abstract}
The microbiological contamination of reindeer carcasses was studied in 10 Finnish reindeer slaughterhouses. Six of the slaughterhouses were field slaughterhouses and four were plant slaughterhouses. In each slaughterhouse 11 to 30 carcasses were sampled, with abdomen, brisket, and foreleg as sampling sites. Sampling was performed immediately after slaughter, using a nondestructive swabbing method. The overall mean bacterial count of carcasses was $3.12 \pm 0.61 \log \mathrm{CFU} / \mathrm{cm}^{2}$. The mean bacterial value of the carcasses and the bacterial counts of abdomen and brisket were significantly lower in field slaughterhouses than in plant slaughterhouses, suggesting that the controlled conditions of plant slaughterhouses do not necessarily improve the microbiological quality of reindeer carcasses. However, the highest bacterial contamination was found in a field slaughterhouse where the slaughter was performed after rain when the ground was without snow. Carcass contamination seemed to be increased by the use of an evisceration apron, the unnecessary washing of forelegs, and the unnecessary handling of carcasses with hands and arms.
\end{abstract}

Reindeer (Rangifer t. tarandus L.) husbandry is important as a traditional source of livelihood in northern parts of Finland. In recent decades, reindeer meat production has developed from household use into the industrial production of processed meat products. Reindeer are slaughtered in special slaughterhouses, either in the field or in plants; the two types of slaughterhouses differ markedly from each other. Plant slaughterhouses resemble those used for domestic animals. Field slaughterhouses, on the other hand, consist of a roof and floor or of simple moveable beams set up outdoors. The procedure for slaughtering reindeer resembles most closely the slaughtering of lambs. After bleeding, the skin is partly removed, with the reindeer in a lying position on a cradle, and the carcass is then hoisted onto a rail for hide pulling and evisceration.

Information is needed concerning the hygienic status of reindeer meat, and the effect of different slaughter conditions and techniques on hygiene, to obtain meat of high hygienic quality for further processing. Attention has been focused on the improvement of hygiene in reindeer meat production by legislation concerning the structural and functional conditions of reindeer slaughtering and slaughterhouses; this legislation also aims to replace field slaughterhouses with plant ones (1).

In a previous study, we showed that microbiological contamination of the reindeer carcass immediately after slaughter varies according to sampling site; this was assumed to be caused by the technique used in reindeer slaughtering (12). The most contaminated sites of the carcasses were the foreleg, brisket, and abdomen. For some

* Author for correspondence. Tel: 358-9-70 849 702; Fax: 358-9-70 849

718; E-mail: Hannu.Korkeala@Helsinki.fi. sampling sites, differences were also detected between the three slaughterhouses studied; these differences were suggested to be due to differences in slaughter technique and hygiene. The purpose of the present survey was to study the microbiological quality of reindeer carcasses in Finnish reindeer slaughterhouses and to compare the microbiological contamination of carcasses slaughtered in field and plant slaughterhouses. The hygiene of the slaughter technique and working habits in reindeer slaughtering were also examined.

\section{MATERIALS AND METHODS}

Sampling procedure and microbiological analyses. Ten reindeer slaughterhouses in Northern Finland were visited on one occasion each. Four of the slaughterhouses were plant slaughterhouses and six were field slaughterhouses. The sampling was performed from October until February, and the average monthly temperature varied from 5 to $-15^{\circ} \mathrm{C}$. On each visit, 11 to 30 reindeer carcasses were sampled, making a total of 258 carcasses. Three sites were sampled from each carcass: the abdomen, brisket, and foreleg (plantar surface). The carcasses were sampled alternately on the left and right sides by the modified, nondestructive swabbing method of Lasta and Fonrouge (4). The samples were taken at the end of the slaughter line before chilling. Altogether 763 samples were analyzed. The pour plate method (5) with plate count agar (Difco Laboratories, Detroit, Mich.) was used in the bacterial examination of carcasses. The sampling method and microbiological analyses used are described in detail by Vaarala and Korkeala (12).

Observation of slaughter technique and working habits. The slaughter procedure of reindeer was observed by one of the authors (A.V.), and the slaughter technique and working habits of each workplace were registered. 
TABLE 1. The mean bacterial count and SD of the reindeer carcasses in 10 slaughterhouses

\begin{tabular}{ccl}
\hline Slaughterhouse & $\begin{array}{c}\text { Number of } \\
\text { carcasses }\end{array}$ & \multicolumn{1}{c}{$\begin{array}{c}\text { Mean } \pm \mathrm{SD} \\
\text { bacterial count } \\
\left(\log \mathrm{CFU} / \mathrm{cm}^{2}\right)^{a}\end{array}$} \\
\hline Field & & $2.85 \pm 0.50 \mathrm{MN}$ \\
A & 30 & $2.72 \pm 0.43 \mathrm{MN}$ \\
B & 26 & $3.98 \pm 0.24 \mathrm{P}$ \\
C & 23 & $2.27 \pm 0.37 \mathrm{~L}$ \\
D & 10 & $2.75 \pm 0.35 \mathrm{MN}$ \\
E & 14 & $3.29 \pm 0.29 \mathrm{O}$ \\
F & 29 & $3.06 \pm 0.62$ \\
Subtotal & 132 & $3.84 \pm 0.40 \mathrm{P}$ \\
Plant & & $2.91 \pm 0.28 \mathrm{~N}$ \\
G & 29 & $2.55 \pm 0.35 \mathrm{LM}$ \\
H & 29 & $3.43 \pm 0.35 \mathrm{O}$ \\
I & 30 & $3.18 \pm 0.60$ \\
J & 30 & $3.12 \pm 0.61$ \\
Subtotal & 118 &
\end{tabular}

${ }^{a}$ Means within a column followed by different letters (L, M, N, $\mathrm{O}$, and $\mathrm{P}$ ) are significantly different (Tukey's test).

Statistical analyses. The statistical programs Systat 6.0.1 (Systat Inc., Chicago, Ill., USA) and GraphPad InStat 2.05 (GraphPad Software, San Diego, Calif.) were used for statistical analyses. The counts were analyzed in logarithmic form (10). Contrasts of the analysis of variance were used to test the differences for mean bacterial counts and the bacterial counts of sampling sites between field and plant slaughterhouses and also between slaughterhouses. The mean bacterial counts of all slaughterhouses were tested by one-way analysis of variance and pairwise by Tukey's test. In each slaughterhouse the bacterial counts of the three sampling sites were compared by one-way analysis of variance; a pairwise comparison was also made by Tukey's test.
The order in the level of contamination on the three sampling sites within the carcass in plant and field slaughterhouses was tested by Friedman's two-way analysis of variance and further by Dunn's Multiple Comparisons Test. Contrasts of the analysis of variance were used to compare some of the differences in slaughter technique and working habits. This comparison was made separately within the groups of five field slaughterhouses (A, B, C, D, and F) and four plant slaughterhouses (G, H, I, and J).

\section{RESULTS}

Microbiological contamination of reindeer carcasses in different slaughterhouses. The overall mean bacteria count and SD of the reindeer carcasses was $3.12 \pm 0.61$ $\log \mathrm{CFU} / \mathrm{cm}^{2}$ (Table 1 ). Only carcasses with a value for all three sampling sites available were included. The mean bacterial values for the group of field slaughterhouses were found to be significantly lower than the mean values for the group of plant slaughterhouses tested by contrasts $(P<$ $0.001)$. The highest mean bacterial count of the carcasses was detected in field slaughterhouse $\mathrm{C}$.

The bacterial counts for abdomen and brisket were significantly higher in plant than in field slaughterhouses (abdomen $P<0.001$, brisket $P<0.01$ ) (Table 2). No significant difference between plant and field slaughterhouses was detected in the contamination of forelegs. The highest mean bacterial values for brisket and foreleg were detected in field slaughterhouse C. This slaughterhouse had one of the highest bacterial counts for abdomen samples as well. The difference between the bacterial counts for slaughterhouse $\mathrm{C}$ and the other nine slaughterhouses was significant $(P<0.001)$ for all three sampling sites.

The bacterial counts for the three sampling sites in different slaughterhouses are shown in Table 2. The bacterial counts did not differ significantly for slaughterhouses B, G, and I. Bacterial counts for the abdomen were significantly lower than counts for the brisket and foreleg in slaughter-

TABLE 2. The bacterial count and SD $\left(\log C F U / \mathrm{cm}^{2}\right)$ of 3 sampling sites in 10 slaughterhouses

Sampling site ${ }^{a}$

\begin{tabular}{llll}
\cline { 2 - 3 } Slaughterhouse & Bbdomen & Brisket
\end{tabular}

Field

$\begin{array}{cll}\text { A } & 3.13 \pm 0.81 \mathrm{M} & (30) \\ \mathrm{B} & 2.88 \pm 0.57 \mathrm{~L} & (28) \\ \mathrm{C} & 3.63 \pm 0.40 \mathrm{~L} & (23) \\ \mathrm{D} & 2.32 \pm 0.88 \mathrm{LM} & (10) \\ \mathrm{E} & 2.49 \pm 0.43 \mathrm{~L} & (14) \\ \text { F } & 2.82 \pm 0.39 \mathrm{~L} & (30) \\ \text { Subtotal } & 2.96 \pm 0.71 & \end{array}$

Plant

$\begin{array}{lll}\text { G } & 3.86 \pm 0.67 \mathrm{~L} & (30) \\ \mathrm{H} & 3.19 \pm 0.47 \mathrm{M} & (29) \\ \mathrm{I} & 2.53 \pm 0.61 \mathrm{~L} & (30) \\ \mathrm{J} & 3.67 \pm 0.59 \mathrm{M} & (30) \\ \text { Subtotal } & 3.31 \pm 0.78 & (119) \\ \text { al } & 3.13 \pm 0.76 & (254\end{array}$

$2.51 \pm 0.52 \mathrm{~L}$
$2.52 \pm 0.58 \mathrm{~L}$
$4.14 \pm 0.34 \mathrm{M}$
$1.89 \pm 0.37 \mathrm{~L}$
$2.83)$
$2.84 \pm 0.76 \mathrm{LM}(11)$
$3.49 \pm 0.43 \mathrm{M}$
$2.98 \pm 0.85$

$3.71 \pm 0.59 \mathrm{~L}$
$2.79 \pm 0.41 \mathrm{~L}$
$2.51 \pm 0.53 \mathrm{~L}$
$3.42 \pm 0.48 \mathrm{LM}$
$3.11 \pm 0.70$
3.04
$3.04 \pm 0.79$

$2.92 \pm 0.72 \mathrm{LM}(30)$
$2.68 \pm 0.91 \mathrm{~L} \quad(26)$
$4.17 \pm 0.23 \mathrm{M}$
$2.62 \pm 0.39 \mathrm{M}$
$3.05 \pm 0.49 \mathrm{M}$
$3.55 \pm 0.46 \mathrm{M}$
$3.22 \pm 0.81$

${ }^{a}$ Means within a row followed by different letters (L and M) are significantly different (Tukey's test). Number of samples are in parentheses. 
houses $\mathrm{C}$ and $\mathrm{F}$, while the reverse was true for slaughterhouse H (Table 2). According to Friedman's nonparametric repeated measures test, in the field slaughterhouses the foreleg was more contaminated within a given carcass than the abdomen or brisket, while in the plant slaughterhouses the abdomen was more contaminated than the foreleg or brisket.

Observation of the slaughter procedure. In the reindeer slaughterhouses observed in this study, the slaughtering technique and the order of individual procedures varied widely. There were no slaughter lines with the same slaughter procedures.

The evisceration of the reindeer carcass is usually performed either on a cradle, by grasping the stomachs and intestines in the arms, or, with the carcass hoisted, by letting the alimentary tract drop into a waste container. In slaughterhouses F, G, and J, an evisceration apron was used. The lower part of the apron was tied around the slaughterman's waist and the other end was attached with hooks to the groins of the hoisted carcass. The stomachs and intestines were dropped into the apron, the hooks removed, and the stomachs and intestines then dropped into the waste container. The back side of the apron was visually dirty in all three slaughterhouses and could have contributed to contamination, primarily on the brisket, which it touched. In both field and plant slaughterhouses, those slaughterhouses that used the apron had significantly higher $(P<0.001)$ brisket bacterial counts than slaughterhouses not using the apron.

The end of the neck is usually hairy and dirty and therefore should be washed with a handheld device. In slaughterhouses B, C, F, and $\mathrm{H}$, the forelegs were washed unnecessarily at the same time, and bacteria might have spread from the neck to the forelegs. The bacterial counts on the forelegs were significantly higher $(P<0.001)$ in slaughterhouses where the forelegs were washed compared with the bacterial contamination of unwashed forelegs.

Unnecessary handling of the carcass when removing the hide was noted both in field and plant slaughterhouses. When evaluating the field slaughterhouses, the unnecessary handling of the abdomen (slaughterhouses A, B, C, and F) was found to increase the contamination of this area significantly $(P<0.001)$. However, the handling of the brisket (slaughterhouses A, B, and F) was not found to increase the contamination. The phenomenon could not be tested on the forelegs because these were handled in every field slaughterhouse. When evaluating the plant slaughterhouses, the handling of carcasses increased contamination significantly on the brisket (slaughterhouses $\mathrm{G}$ and $\mathrm{H} ; P<0.01$ ) and foreleg $(\mathrm{G}, \mathrm{H}$, and $\mathrm{J} ; P<0.001)$ but not on the abdomen.

Washing facilities and washing habits were recorded in seven slaughterhouses. For the washing of hands and knives in field slaughterhouse A, there were two water pails for six slaughtermen; of these, three washed their hands and tools occasionally, and the other three not once during the slaughter. In slaughterhouse B, there was one pail and one handheld device for nine slaughtermen, none of whom washed their hands or tools during the slaughter. In slaughterhouse F, there was one handheld device, which was used to wash the inside of the carcass; none of the twelve slaughtermen washed their hands or tools during the slaughter. In the field slaughterhouses, there was no possibility of disinfection. Plant slaughterhouses G, H, I, and J had two, three, three, and four waterbasins and four, one, one, and two handheld devices, respectively; two of seven, nine of ten, three of five, and four of six slaughtermen, respectively, did not wash their hands or tools at all during the slaughtering process. In plant slaughterhouse G, five of the seven slaughtermen washed occasionally, and in plant slaughterhouses $\mathrm{H}, \mathrm{I}$, and $\mathrm{J}$, one of ten, two of five, and two of six slaughtermen, respectively, washed their hands and tools once per carcass. In the plant slaughterhouses, there were a total of ten sterilizers, but none of them were working during the slaughter.

\section{DISCUSSION}

The mean bacterial counts of the reindeer abdomen, brisket, and forelegs were at about the same level in this study as in our previous one (12) and of about the same order of magnitude as those found in other studies for the same parts of carcasses of domestic animals $(2,3,6,9,11)$.

The mean bacterial counts of the reindeer carcasses and the bacterial contamination of the abdomen and brisket were significantly lower in field than in plant slaughterhouses. It is possible that in field slaughterhouses the cold and dry weather impairs the viability of bacteria in the air and on hands, tools, and other surfaces; snow on the ground may also reduce microbiological contamination from the environment to the carcasses. Moreover, in field slaughterhouses the chilling of the carcass surface starts immediately after the hide is removed, which may affect both bacterial growth and the number of bacteria determined with the sampling method used.

In the present study, field slaughterhouse $\mathrm{C}$ had significantly higher bacterial counts than the other slaughterhouses. Slaughterhouse $\mathrm{C}$ was the only one in which the slaughter was performed after rainfall when the ground had no snow on it. The fact that the slaughtering conditions and the reindeer were dirtier in this slaughterhouse than in the other slaughterhouses could be the reason for the high levels of bacterial contamination. Ridell and Korkeala (8) have also shown that a layer of dung on cattle hide increases the surface bacterial contamination of carcasses. These observations suggest that when slaughtering is performed under optimal weather conditions, for instance, when there is enough snow on the ground and when the temperature is cold enough to chill the carcasses, the microbiological quality of reindeer meat processed in field slaughterhouses may be better than in plant slaughterhouses. In early autumn, on the other hand, when weather conditions are not necessarily optimal for slaughtering, the microbiological contamination of reindeer carcasses may be considerably higher, resembling the bacterial contamination seen in field slaughterhouse C. However, in the effort to produce reindeer meat of high quality in field slaughterhouses, uncontrolled weather conditions are a major drawback, whereas in plant 
slaughterhouses the controlled conditions are an indisputable advantage. Special attention should be focused on minimizing bacterial contamination during slaughter in field slaughterhouses under poor weather conditions. One solution might be to prohibit slaughtering in field slaughterhouses when weather is too warm or humidity too high for proper chilling of carcasses or when there is a possibility of contamination of carcasses due to dirtiness of animals or slaughter facilities.

The variation in the reindeer slaughtering procedure observed in the present study may explain some of the differences in the bacterial contamination of carcasses in different slaughterhouses. Some slaughtering techniques and working habits seemed to increase the contamination of carcasses: the use of an evisceration apron, the unnecessary washing of forelegs, and the unnecessary handling of carcasses with hands and arms. The hygienic practices of workers, in particular disinfection frequency, seem to be associated with carcass contamination (6). In these slaughterhouses, washing and sterilization facilities and habits were poor even in the plant slaughterhouses, which should have an advantage over field slaughterhouses with regard to hygiene. In the plant slaughterhouses studied, the level of structural hygiene was not satisfactory. It is important that slaughtering lines be designed in such a way as to make hygienic working possible $(6,7)$. Structural changes are needed to obtain proper washing and sterilizing facilities in these plant slaughterhouses. Furthermore, the slaughtermen did not make use of the washing and sterilizing facilities available in plant slaughterhouses. Adequate washing facilities can be obtained even in field slaughterhouses by installing a water tank and heating the water in the slaughterhouse and using a water pail or a handheld device to pour the water over the hands and tools. Disinfection, however, is more difficult to arrange in field conditions. The code of good manufacturing practices should be carried out in every reindeer slaughterhouse. The education of both slaughtermen and reindeer meat inspectors is important in this respect.

In conclusion, reindeer carcasses were microbiologi- cally cleaner after slaughter in field slaughterhouses than in plant slaughterhouses. Reindeer meat of high hygienic quality can be produced in field slaughterhouses; under ideal weather conditions, the microbiological contamination of meat during slaughter is in fact even lower than in plant slaughterhouses. According to our findings, the improvement of the microbiological quality of reindeer carcasses cannot serve as a basis for recommending slaughtering reindeer in plant slaughterhouses or totally prohibiting slaughtering in field slaughterhouses.

\section{REFERENCES}

1. Anonymous. 1995. Poron lihantarkastus sekä poroteurastamolle asetettavat hygieniavaatimukset (poronlihahygieniapäätös). Statute 18/ EEO/95. Veterinary and Food Department, Ministry of Agriculture and Forestry, Helsinki, Finland.

2. Ingram, M., and T. A. Roberts. 1976. The microbiology of the red meat carcass and slaughterhouse. Roy. Soc. Health J. 96:270-276.

3. Johanson, L., B. Underdal, K. Grosland, O. P. Whelehan, and T. A. Roberts. 1983. A survey of the hygienic quality of beef and pork carcasses in Norway. Acta Vet. Scand. 24:1-13.

4. Lasta J., and R. Fonrouge. 1988. Significance of samples taken for bacterial counts from reduced areas of bovine carcasses. J. Food Prot. 51:214-217.

5. Nordic Committee on Food Analysis. 1986. Aerobic micro-organisms. Enumeration at $30^{\circ} \mathrm{C}$ in meat and meat products. Method no. 86, 2nd ed. Technical Research Centre of Finland, SF-02150 Espoo, Finland.

6. Rahkio, M., and H. Korkeala. 1996. Microbiological contamination of carcasses related to hygiene practice and to facilities on slaughtering lines. Acta Vet. Scand. 37:219-228.

7. Rahkio, M., and H. Korkeala. 1997. Airborne bacteria and carcass contamination in slaughterhouses. J. Food Prot. 60:38-42.

8. Ridell, J., and H. Korkeala. 1993. Special treatment during slaughtering in Finland of cattle carrying an excessive load of dung; meat hygienic aspects. Meat Sci. 35:223-228.

9. Roberts, T. A. 1980. The effects of slaughter practices on the bacteriology of the red meat carcass. Roy. Soc. Health J. 100:3-9.

10. Roberts, T. A., H. J. H. MacFie, and W. R. Hudson. 1980. The effect of incubation temperature and site of sampling on assessment of the numbers of bacteria on red meat carcasses at commercial abattoirs. J. Hyg. Camb. 85:371-380.

11. Stolle, F. A. 1988. Establishing microbiological surveillance programmes at slaughterlines - a new concept of meat hygiene. Meat Sci. 22:203-211.

12. Vaarala, A., and H. Korkeala. 1994. Microbiological contamination of reindeer carcass during slaughter. Acta Vet. Scand. 35:383-388. 